\title{
Analysis and Predicting the Energy Consumption of Low-Pressure Carburising Processes
}

\author{
Sławomir Kłos ${ }^{1}$, Justyna Patalas-Maliszewska ${ }^{1, *(\mathbb{D}, \text {, Lukasz Piechowicz }}{ }^{2}$ and Krzysztof Wachowski ${ }^{2}$ \\ 1 Institute of Mechanical Engineering, University of Zielona Góra, 65-417 Zielona Góra, Poland; \\ S.Klos@iim.uz.zgora.pl \\ 2 Seco Warwick SA, 8 Sobieskiego Str., 66-200 Świebodzin, Poland; Lukasz.Piechowicz@secowarwick.com (Ł.P.); \\ Krzysztof.Wachowski@secowarwick.com (K.W.) \\ * Correspondence: J.Patalas-Maliszewska@iim.uz.zgora.pl
}

check for updates

Citation: Kłos, S.;

Patalas-Maliszewska, J.; Piechowicz,

Ł.; Wachowski, K. Analysis and

Predicting the Energy Consumption

of Low-Pressure Carburising

Processes. Energies 2021, 14, 3699.

https://doi.org/10.3390/en14123699

Academic Editor: Tomislav Capuder

Received: 24 April 2021

Accepted: 15 June 2021

Published: 21 June 2021

Publisher's Note: MDPI stays neutral with regard to jurisdictional claims in published maps and institutional affiliations.

Copyright: (c) 2021 by the authors. Licensee MDPI, Basel, Switzerland. This article is an open access article distributed under the terms and conditions of the Creative Commons Attribution (CC BY) license (https:/ / creativecommons.org/licenses/by/ $4.0 /)$.

\begin{abstract}
The monitoring of the performance of heat treatment equipment has been the subject of a number of studies. This paper proposes and explores a new study on the models-and the monitoring thereof-for predicting the energy intensity of low-pressure carburisation processes using the DeepCaseMaster Evolution soaking furnace. For research purposes, 18 carburising experiments were performed with different carbon layers, at different input parameters, such as the number of cycles, time, temperature and average carburising pressure. Based on the research experiments conducted and statistical analysis, the influence of individual parameters on the energy consumption of the pump and heating systems was determined. Moreover, the models were verified on real data of low-pressure carburising processes. The innovativeness of the proposed solution is a combination of two areas: (1) defining and measurement of the parameters of the low-pressure carburising process; and (2) predicting the energy consumption of low-pressure carburising processes using correlation and regression analyses. The possibilities of using the results of this research in practice are demonstrated convincingly.
\end{abstract}

Keywords: energy consumption of low-pressure carburising processes; analysis of the energy intensity; statistical analysis

\section{Introduction}

The implementation of predictive methods of maintenance into industrial practice is one of the key assumptions of Industry 4.0. Production resources should be integrated with systems for diagnosing possible emergency situations. This approach allows losses associated with damaged products, due to the occurrence of failures and unplanned downtime, to be reduced and reduces the cost of maintaining specialist, technical personnel, such as automatics and mechanics. Systems for monitoring the performance of complex technical systems are particularly important when they are located in regions where access to qualified, technical personnel is especially limited.

In order to improve the efficiency of a maintenance department, it is usually necessary to establish a working schedule, based on the prediction of failure(s) within the system and on the historical data of the useful life of the system as well as planning and carrying out maintenance activities [1]. Monitoring the operating parameters of equipment is a fundamental task for maintenance services. However, the predictive planning of maintenance for technical systems remains an open area, due to the specific features of these systems, including energy intensity [2]. In the literature, there are good examples of developing predictive models for technical systems: predictive optimisation of the maintenance of a single biomass boiler $[3,4]$. However, their application is limited to the test site of a given object. In this article, research has been undertaken on the development of a predictive model for the intensity of the energy of low-pressure carburisation processes, taking into account the special features of the technical system. The introduction and review of 
methods, related to predictive maintenance, has been the subject of research carried out by many authors [5,6]. Predictive maintenance methods apply Markov's processes, Bays networks, artificial neural networks and simulation methods based, for example, on the Monte Carlo method [7]. Building predictive models involves the collection and storage of data, using machine learning algorithms, such as regression analysis, artificial neural networks, and classifiers [8]. Many publications cover the application of machine learning methods for predictive maintenance [9], based on an analysis of machine performance [10] and production environment variables [11]. Part of the research concerns the acquisition and storage of data in the cloud and the construction of a system platform for the needs of predictive maintenance [12].

The specific nature of the undertaken research problem and the market demand for project results can be illustrated using the following data. The heat treatment market is very diverse, due to the wide variety of machining inputs, the intended purpose of the parts, the conditions of their operation, the manufacturing technology, the location of the process in the production cycle, etc. For these reasons, the value of one-off processed inputs can range from several thousand to even several hundred thousand euros. In both the energy and mining industries, due to the large size and high production costs of individual parts, the value of machined batches often exceeds 100 thousand EUR. The heat treatment of these components is often the last, or penultimate, process in the production cycle. In extreme cases, the value of the one-off processing of a batch may exceed the value of the equipment, with the heat treatment of very expensive, key elements such as pipes for the construction of the nuclear reactor heat exchangers. Heat treatment can be carried out directly at the manufacturers of individual parts, mechanical components, machines and equipment, or it can be outsourced to service hardening plants. In any case, heat treatment operators bear the risk of financial loss as a result of incorrectly performed processes. Besides the human factor, the most common causes of damage or destruction of the inputs treated are breakdowns and malfunctions in the operation of the heat treatment equipment. The cumulative breakdown costs may include the costs of the input, repair costs, equipment start-up costs and downtime costs.

Low-pressure carburisation is one of several long-term and energy-intensive heat treatment processes, especially when thick layers of carburisation are required. Processing can take up to several hours with the temperature maintained in the furnace chamber, having a value of approximately $1000^{\circ} \mathrm{C}$ and a vacuum level of approximately $10^{-1} \mathrm{mbar}$. However, it should be emphasised that low-pressure carburisation, in comparison with atmospheric carburisation, is characterised by much lower energy consumption (despite the higher temperature, vacuum carburisation is much shorter-up to a half). LPC is therefore an energy-efficient and environmentally friendly, heat-chemical treatment technology. It follows, from the description, that LPC is, a priori, an energy-intensive technology, thanks to which the best results, in the form of a reduction in the time taken for carburisation, as compared to a traditional technology, such as atmospheric carburisation, can be achieved for thick layers.

The monitoring of the performance of heat treatment equipment has been the subject of a number of studies. New methods [13] and tools-or sensors-are often developed to monitor the carburising processes [14] and often allow the process inside the furnace chamber to be analysed [15]. Part of this research focusses on the construction of vacuum carburisation simulation models, which would allow the optimal process parameters to be selected, in order to obtain a top-layer, carbon-concentration profile in the shortest possible time [16].

A modern trend is to follow the concept of Industry 4.0 (I4.0), where modern manufacturing systems are driven by information technology (IT) and achieve a sustainable society [17]. I4.0 has unlimited potential to build sustainable industrial value in three dimensions: environmental, economic and social. The manufacturing sector needs to arrange low-carbon manufacturing without increasing costs and reducing production efficiency [18]. 
The article presents an analysis of the intensity of the energy of low-pressure carburisation processes, based on a real case study of a manufacturing company. Eighteen low-pressure carburisation processes were analysed to obtain various thickness levels of the carburisation layers:

- a thin layer of up to approximately $0.5 \mathrm{~mm}$;

- a medium layer of up to approximately $1.5 \mathrm{~mm}$; and

- a thick layer of up to approximately $4 \mathrm{~mm}$.

The system for monitoring the furnace parameters recorded the temperature of the furnace chamber, the pressure, the power consumption and the number of carburising cycles. An approach to predicting the energy consumption during the low-pressure carburising process was developed.

The second chapter of this article indicates the methods and materials, as well as the research gap, based on an analysis of the current state of research. Based on the analysis carried out - and on a real case study — a need to create a new model was identified. The third part of the article describes the research results and gives details of the possibilities of using the results in real manufacturing companies and formulates a direction for future work.

\section{Materials and Methods}

\subsection{Heat Treatment Processes for Metal and the Operating Parameters of the Vacuum Pit Furnace}

Carburisation is a process for treating metals with heat, consisting of the diffusion and saturation of the top layer of the workpiece with carbon, usually at a temperature of approximately $900-1050^{\circ} \mathrm{C}$. Low-carbon steel parts are usually subjected to carburisation in order to improve their hardness and resistance to wear of the surface layer of the workpiece. The carburising depth is usually $0.2-5 \mathrm{~mm}$ and depends on the time and number of carburising cycles. The hardening process consists of heating the element to the so-called 'hardening temperature', continuing to withstand this temperature in order to rebuild the internal structure of the material and then quickly cooling the part off. As a result of the hardening process, resistance to hardness and abrasion increases. Both carburisation and the hardening of materials under vacuum conditions-that is, lowpressure heat treatment processes - allow for high repeatability of the processed parts to be achieved. Equipment for the heat treatment is usually installed on the process line and is one of the key stages in the production of parts for the aviation and automotive industries. A potential breakdown of the furnace for heat treatment can cause the entire production line to stop, which entails huge costs and incurs heavy penalties. Heat treatment plants are relatively expensive, and few companies can afford to maintain redundant resources. They are therefore used, maximally, in a two- or three-shift system. Hence, it is very important to predict potential breakdowns and properly plan inspections of such a plant, as well as replace their operating parts. The following sub-systems of the vacuum pit furnace are distinguished: furnace casing and thermal insulation, heating system, gas system, water system, pneumatic system and pump system. A reduction in carburisation time can result in a reduction in production costs and energy consumption of up to $5-50 \%$, depending on the thickness of the carburising layer [19].

\subsection{A Case Study}

The SECO/WARWICK Co. S.A. produces heat treatment equipment for metal. These devices are used in manufacturing companies, in complex technological processes, in the manufacture of components for control systems, transmissions, aircraft landing systems, turbines, aircraft engine blades and in heat exchangers in aircraft and cars. Currently research focuses on the development of an autonomous monitoring and processing system in low-pressure carburisation processes. The autonomous monitoring system is based on the continuous monitoring and processing of the key working parameters of the individual sub-systems of the furnace. The main task of the installation is to equip the vacuum pit furnace with an early warning system for predictive maintenance. The system makes it possible to reduce the total cost of operating the device, by reducing the downtime, 
reducing maintenance costs and by correctly selecting the operating parameters, in order to ensure the low consumption of energy and process gases, while simultaneously ensuring the preservation of all technological parameters. In addition, the self-diagnosis system allows data, obtained from the vacuum soaking furnace, to be exchanged with other and technological line devices, in accordance with the concept of Industry 4.0. Analysis of the operating data of vacuum furnaces recorded in the Cloud allows the efficiency of warranties and post-warranty customer service to be increased, operating parameters to be improved and better and cheaper equipment to be designed. DeepCaseMaster Evolution heat treatment units, together with the system of "predictive maintenance", as developed, will be dedicated mainly to the energy and mining industries, where it is necessary to produce uniformly thick carbon layers on the relevant components of machines and equipment, such as the drive shafts for wind turbines, gears with large modules, drill bits, cutters, etc. Predictive maintenance makes it possible to improve the efficiency of processes associated with reducing the number of breakdowns, as well as the cost of servicing production resources [20]. The low-pressure carburisation procedure is as follows (Figure 1).

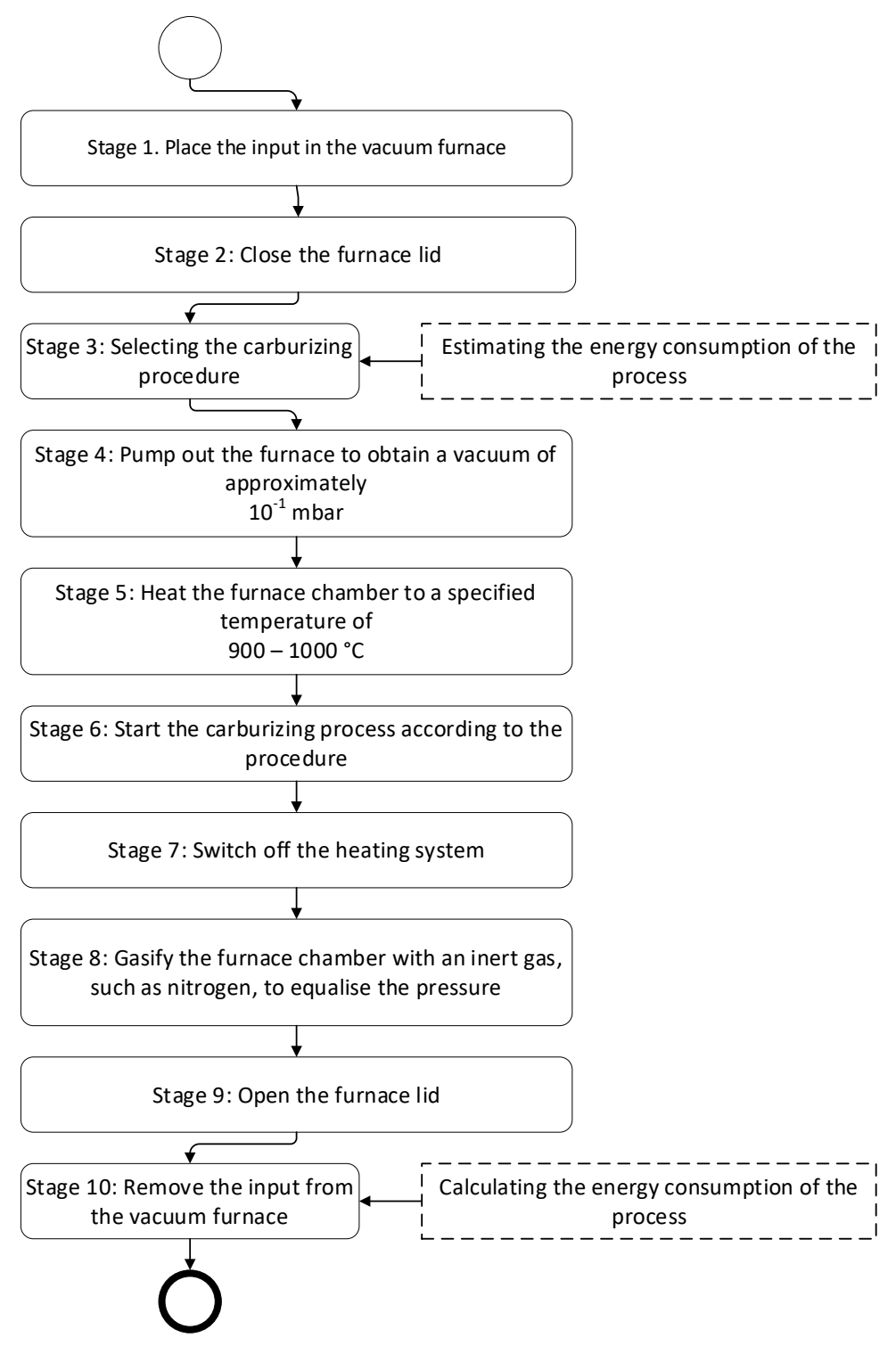

Figure 1. The low-pressure carburisation procedure. 


\subsection{Research Methodology}

Experimental studies were carried out for low-pressure carburisation processes with the following three layers: a thin layer $(0.5-1.5 \mathrm{~mm})$, medium layer $(1.5-4.0 \mathrm{~mm})$ and thick layer (more than $4.0 \mathrm{~mm}$ ) in a vacuum pit furnace at different temperatures, durations and numbers of carburisation cycles. In our research, the AISI 304 low-carbon steel was used. The range of studies included heating temperatures from $860^{\circ} \mathrm{C}$ to $1040{ }^{\circ} \mathrm{C}$, maintaining an average pressure of from 1.05 to 6 mbar and maintaining the number of carburising cycles from 4 to 25 . The duration of the low-pressure carburising processes studied ranged from 3 to $41 \mathrm{~h}$.

Figure 2 shows diagrams describing the process of low-pressure carburisation with a thin layer of carbon. The process was carried out at a temperature of approximately $1040^{\circ} \mathrm{C}$, a pressure, measured in the furnace chamber, of approximately $0.3 \mathrm{mbar}$ and four cycles of acetylene flow. The process started at 13.40, when the mechanical pump was turned on and ended at 17.10, when the mechanical pump was turned off. The heating process started at 14.00 , at a pressure of approximately 0.28 mbar. Carburising with acetylene began at 16.05 when the temperature reached the assumed level of $1041^{\circ} \mathrm{C}$. In the example presented, the carburising procedure involved four cycles of the administration of acetylene. The marker, shown in the diagram, indicates the starting time of the heating process. The temperature graph shows that the heating proceeded at a speed (ramp) of $10^{\circ} \mathrm{C} / \mathrm{min}$ and started after the assumed vacuum was reached, below 0.3 mbar. In the low-pressure carburisation process, the heating and pump systems are the most energy-intensive subsystems of the furnace. The instantaneous energy consumption during each experiment was measured for both of these online sub-systems. The total power consumption was calculated by integrating the numerical waveforms by means of numerical integration using the trapezoidal method. When energy consumption was sampled, at $1 \mathrm{~s}$ and $4 \mathrm{~s}$ frequencies, accurate results of energy consumption were obtained for both furnace sub-systems.

Figure 3 shows a diagram of the power consumption of the heating and pumping system. The maximum energy consumption of the heating system occurs during the heating process when reaching a certain temperature level—for the example under consideration, it was $1040^{\circ} \mathrm{C}$-while in the example presented it was $13 \mathrm{~kW}$. The power consumption of the pump system was $1.82 \mathrm{~kW}$ until the carburisation process started.

After the first cycle of acetylene carburisation, due to the increase in pressure in the furnace chamber, an increase in energy consumption by the mechanical pump can be observed; this is due to the increase in pressure in the furnace chamber. The power consumption of the pump and heating systems was determined using numerical integration; for the power consumption diagrams shown in Figure 3, the energy consumption of the heating system (a) was $19.75 \mathrm{kWh}$, while for the pump system (b) it was $6.46 \mathrm{kWh}$, respectively.

The aim of the present study was to determine the effect of the following input parameters:

- furnace heating temperature;

- $\quad$ average pressure in the furnace chamber; and

- number of carburising cycles and the time taken for carburisation, by the energy consumption of the heating and pump systems.

To this end, 18 research experiments on the predictive low-pressure carburising process were carried out with the same amount of ballast input and different input parameters of the process.

\subsection{Data Collection}

As a result of the 18 research experiments, involving the process of carburisation of the input with layers of various thicknesses, the following data were obtained:

- $\mathrm{Y}_{1}$-energy consumption of the pump system;

- $\mathrm{Y}_{2}$ - energy consumption of the heating system;

- $X_{1}$-number of cycles;

- $\mathrm{X}_{2}$-heating temperatures; 
- $\quad \mathrm{X}_{3}$-pressure;

- $\mathrm{X}_{4}$-time (min).

a)

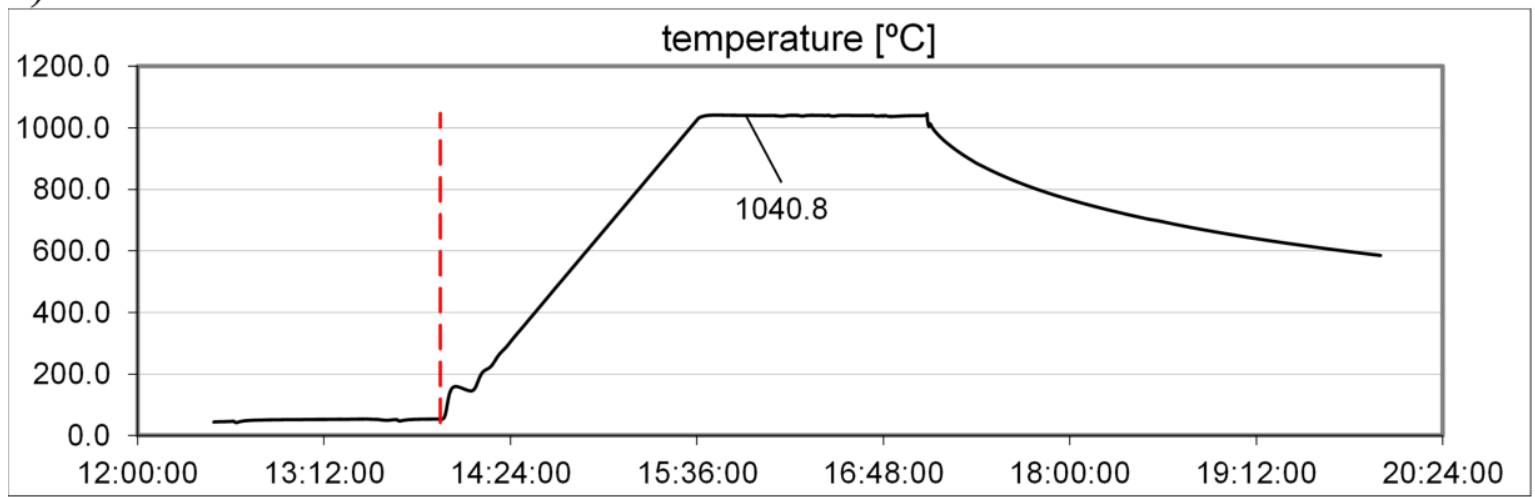

b)

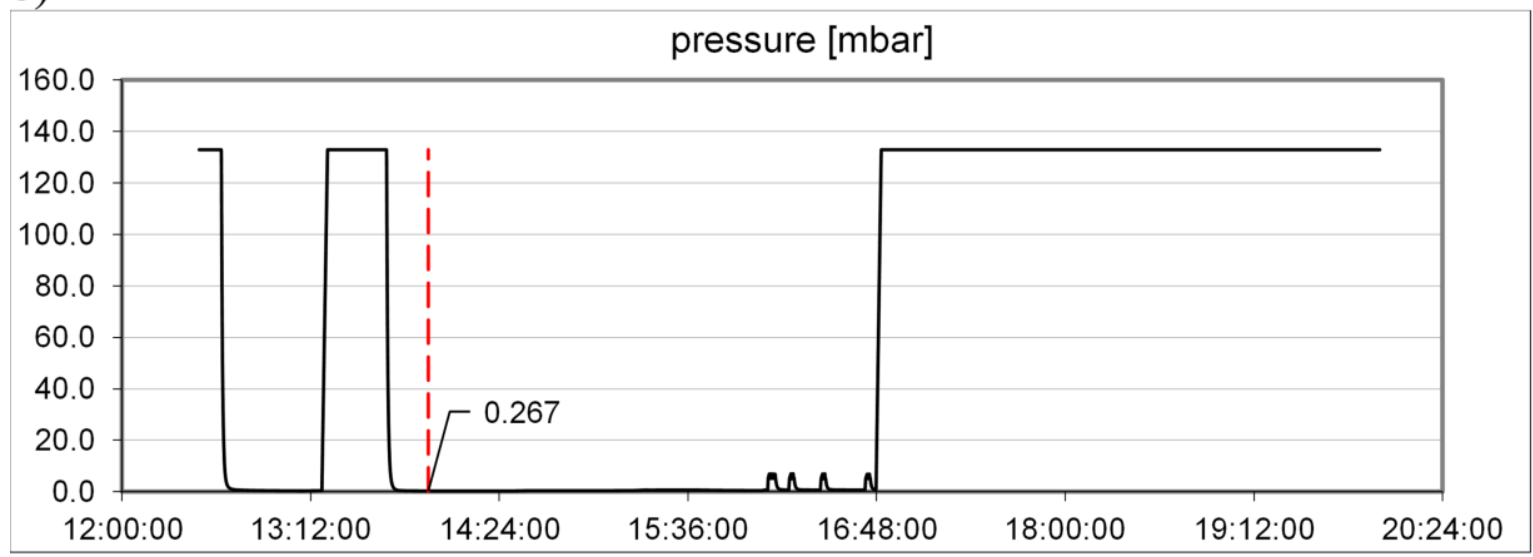

c)

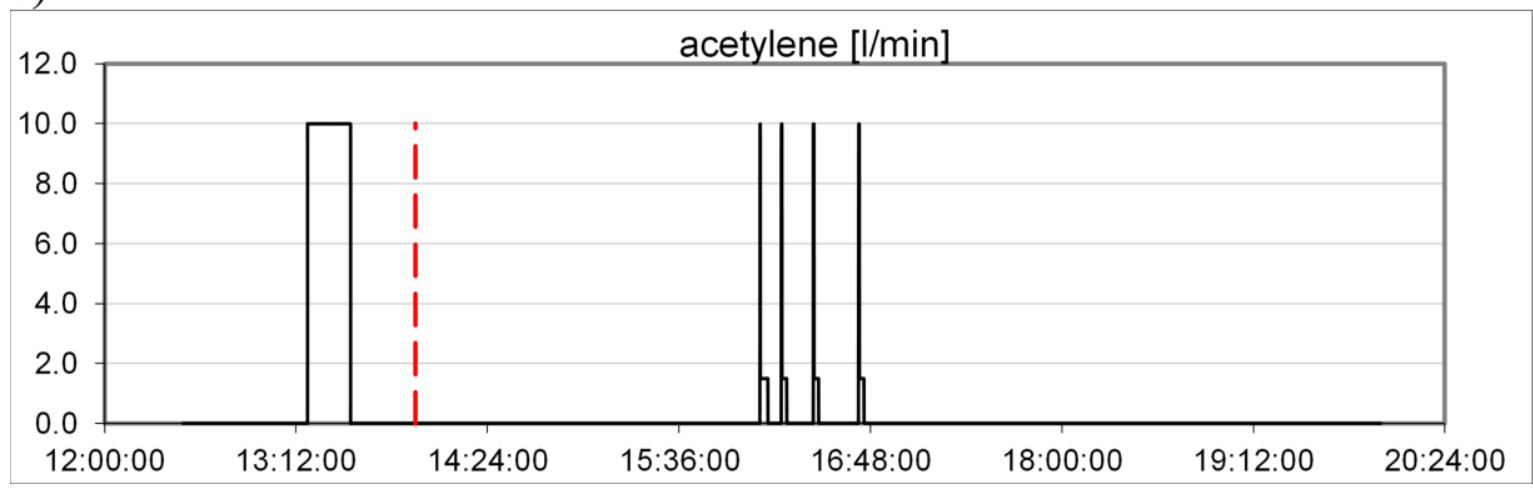

Figure 2. Changes in temperature (a), pressure (b) and acetylene flow (c) during the low pressure carburisation process.

The research took some 6 months due to the duration of the carburising processes, especially in the case of medium and thick layers using the DeepCaseMaster Evolution furnace. Carburisation processes were implemented on the basis of procedures that precisely define the input parameters of the process. Table 1 shows the results of the research experiments ordered, according to the number of carburising cycles. The first seven experiments show the parameters of the input carburisation with a thin layer of carbon, the number of cycles being 4-5. Experiments 8 to 14 show the results of the carburisation tests with the average layer of the carbon, the number of cycles being 11, while the last four experiments have the number of cycles as 22-25. As shown in Table 1, both the carburising 
time and the energy consumption vary according to the thickness of the carburisation layer to be obtained.
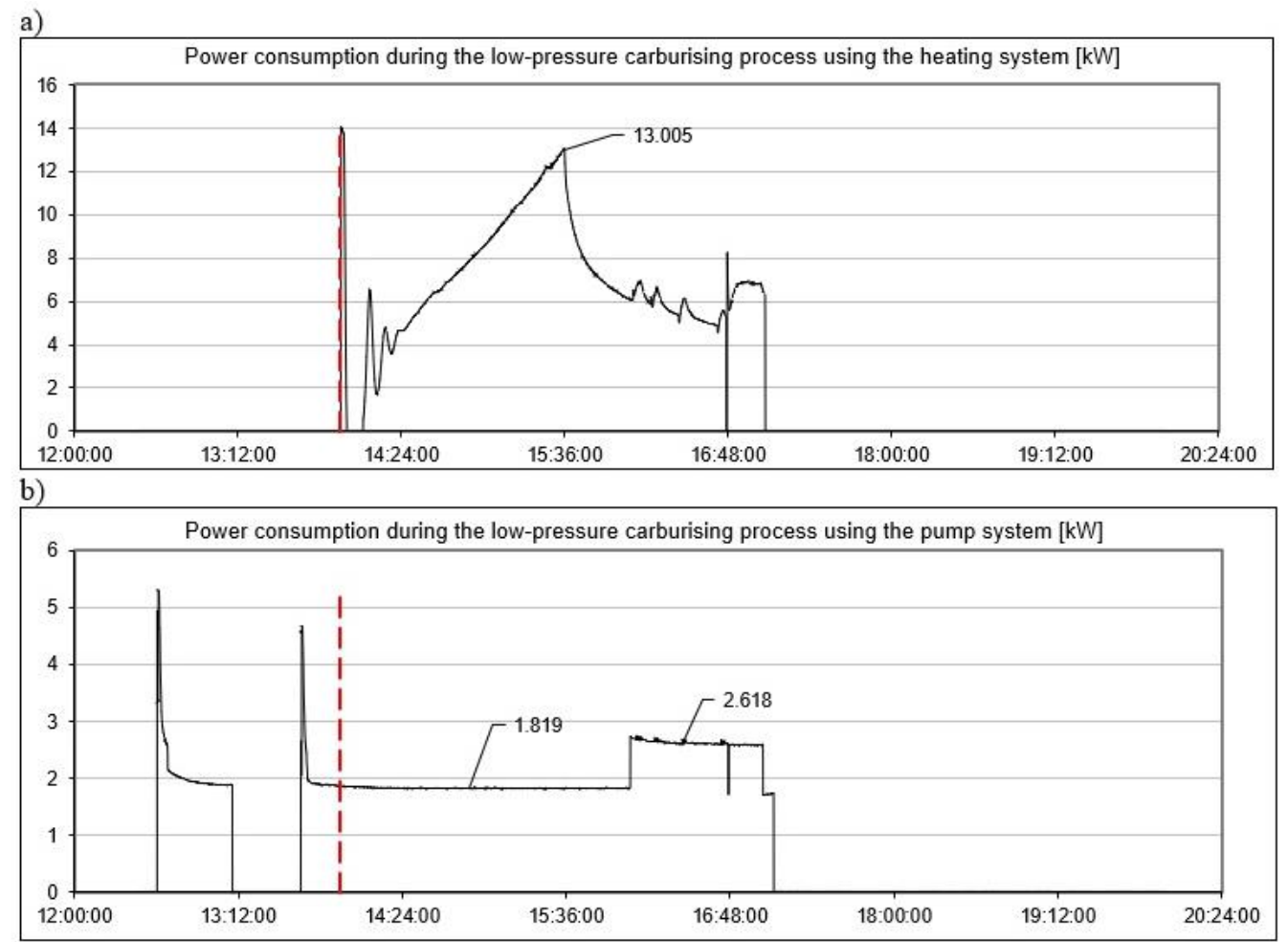

Figure 3. Power consumption during the low-pressure carburising process using the heating system (a) and pump system (b).

Table 1. Results of the research experiments.

\begin{tabular}{|c|c|c|c|c|c|c|}
\hline No. & $\begin{array}{l}\text { Number of } \\
\text { Cycles- } X_{1}\end{array}$ & $\begin{array}{c}\text { Heating } \\
\text { Temperatures- }-X_{2} \\
\left({ }^{\circ} \mathrm{C}\right)\end{array}$ & $\underset{(\mathrm{mbar})}{\text { Pressure- }} \mathrm{X}_{3}$ & $\underset{(\min )}{\text { Time}-X_{4}}$ & $\begin{array}{c}\text { Energy } \\
\text { Consumption of the } \\
\text { Pump System } \\
(\mathrm{kWh})-\mathrm{Y}_{1}\end{array}$ & $\begin{array}{c}\text { Energy } \\
\text { Consumption of the } \\
\text { Heating System } \\
\text { (kWh)- } \mathbf{Y}_{2}\end{array}$ \\
\hline 1 & 4 & 930 & 2.70 & 232 & 8.29 & 19.80 \\
\hline 2 & 4 & 930 & 1.66 & 200 & 7.29 & 16.90 \\
\hline 3 & 4 & 930 & 2.76 & 290 & 10.13 & 18.55 \\
\hline 4 & 4 & 1040 & 1.84 & 190 & 6.46 & 19.75 \\
\hline 5 & 4 & 1040 & 1.56 & 265 & 8.88 & 21.54 \\
\hline 6 & 5 & 960 & 1.47 & 228 & 8.02 & 18.31 \\
\hline 7 & 5 & 960 & 1.34 & 318 & 8.38 & 19.75 \\
\hline 8 & 11 & 860 & 1.10 & 525 & 21.62 & 23.78 \\
\hline 9 & 11 & 860 & 1.18 & 462 & 19.47 & 22.81 \\
\hline 10 & 11 & 860 & 3.58 & 474 & 20.08 & 24.09 \\
\hline 11 & 11 & 950 & 1.62 & 606 & 24.57 & 35.75 \\
\hline 12 & 11 & 950 & 1.87 & 622 & 24.91 & 31.90 \\
\hline 13 & 11 & 950 & 1.30 & 581 & 23.64 & 32,97 \\
\hline 14 & 11 & 950 & 1.38 & 536 & 22.29 & 34.20 \\
\hline
\end{tabular}


Table 1. Cont.

\begin{tabular}{ccccccc}
\hline No. & $\begin{array}{c}\text { Number of } \\
\text { Cycles-X }\end{array}$ & $\begin{array}{c}\text { Heating } \\
\text { Temperatures- } \mathbf{X}_{2} \\
\left({ }^{\circ} \mathbf{C}\right)\end{array}$ & $\begin{array}{c}\text { Pressure- } \mathbf{X}_{3} \\
(\mathbf{m b a r})\end{array}$ & $\begin{array}{c}\text { Time- } \mathbf{X}_{\mathbf{4}} \\
(\mathbf{m i n})\end{array}$ & $\begin{array}{c}\text { Energy } \\
\text { Consumption of the } \\
\text { Pump System } \\
\left(\mathbf{k W h}-\mathbf{Y}_{\mathbf{1}}\right.\end{array}$ & $\begin{array}{c}\text { Consumption of the } \\
\text { Heating System } \\
\left(\mathbf{k W h}-\mathbf{Y}_{\mathbf{2}}\right.\end{array}$ \\
\hline 15 & 22 & 1000 & 1.05 & 2387 & 92.50 & 95.42 \\
16 & 22 & 1000 & 5.61 & 2403 & 99.86 & 97.14 \\
17 & 22 & 1000 & 6.60 & 2460 & 97.53 & 94.72 \\
18 & 25 & 985 & 2.14 & 1314 & 111.72 & 100.79 \\
\hline
\end{tabular}

\section{Results}

In order to investigate the relationship between the data obtained, correlation and regression analyses were applied, using Statistica, version 13.3, software (StatSoft Polska Sp. z o.o., Kraków, Poland). Table 2 shows the correlations for the main variables included in Table 1 using the Statistica software. The data were carefully examined for linearity, equality of variance and normality. No significant deviations were detected.

Table 2. Correlation analysis.

\begin{tabular}{|c|c|c|c|c|}
\hline Factors & Correlation & r2 & $\mathbf{t}$ & $p$ \\
\hline $\begin{array}{l}\text { Energy consumption of the pump } \\
\text { system/number of cycles }\end{array}$ & 0.9630 & 0.9274 & 14.3021 & 0.0000 \\
\hline $\begin{array}{l}\text { Energy consumption of the pump } \\
\text { system/heating temperatures }\end{array}$ & 0.3500 & 0.1225 & 1.4948 & 0.1544 \\
\hline $\begin{array}{l}\text { Energy consumption of the pump } \\
\text { system/Pressure }\end{array}$ & 0.5339 & 0.2851 & 2.5260 & 0.0224 \\
\hline $\begin{array}{l}\text { Energy consumption of the pump } \\
\text { system/time [min] }\end{array}$ & 0.9274 & 0.8600 & 9.9171 & 0.0000 \\
\hline $\begin{array}{l}\text { Energy consumption of the } \\
\text { heating system/number of cycles }\end{array}$ & 0.9493 & 0.9011 & 12.07928 & 0.0000 \\
\hline $\begin{array}{l}\text { Energy consumption of the } \\
\text { heating system/heating } \\
\text { temperatures }\end{array}$ & 0.4194 & 0.1759 & 1.8481 & 0.0831 \\
\hline $\begin{array}{l}\text { Energy consumption of the } \\
\text { heating system/Pressure }\end{array}$ & 0.5266 & 0.2773 & 2.4781 & 0.0247 \\
\hline $\begin{array}{l}\text { Energy consumption of the } \\
\text { heating system/time [min] }\end{array}$ & 0.9424 & 0.8882 & 11.2754 & 0.0000 \\
\hline
\end{tabular}

Note: $r 2$ is the coefficient of determination; $t$ is the value of the $t$ statistic examining the significance of the correlation coefficient; and $p$ is the value of the probability.

The analysis showed the most important relationship between the energy consumption of the pump system, namely, the number of cycles. Therefore, in order to determine the nature of the significant interaction of the influence of the number of cycles on the energy consumption of the pump system, regression analysis (Equation (1)) was carried out in the present study.

Similarly, the analysis (Table 2) showed the most important relationship between the power consumption of the heating system, the number of cycles.

So, the prediction model for the energy consumption of low-pressure carburising processes (Equation (1), Figure 4) was constructed, using multi-variate regression analysis for the main variables included in Table 2 using Statistica software. The data were carefully 
examined for linearity, equality of variance and normality. A linear model was assumed because all variables are equally important within a process of energy consumption of the pump system and energy consumption of the heating system of low-pressure carburising processes. The energy consumption sampling period was $1 \mathrm{~s}$. The pressure value was calculated as the average for the entire duration of each experiment, due to the varying amount of acetylene determined in individual procedures. The amount of energy consumed by the pump and heating system was determined on the basis of numerical integration of the runs in individual research experiments. One parameter-time-was not taken into account in the model because it depends on the number of cycles. No significant deviations were detected.

$$
\begin{aligned}
& \text { Energy consumption of Low }- \text { pressure Carburising Processes } \\
& \qquad \begin{array}{l}
=-143.34+3.81 \times \text { number of cycles } \\
+0.14 \times \text { heating temperatures }+1.82 \times \text { Pressure }
\end{array}
\end{aligned}
$$

and $\mathrm{R}=0.9861 ; \mathrm{R} 2=0.9724$, corrected $\mathrm{R} 2=0.9665 ; \mathrm{F}(3,14)=164.61 ; p=0.0000$.
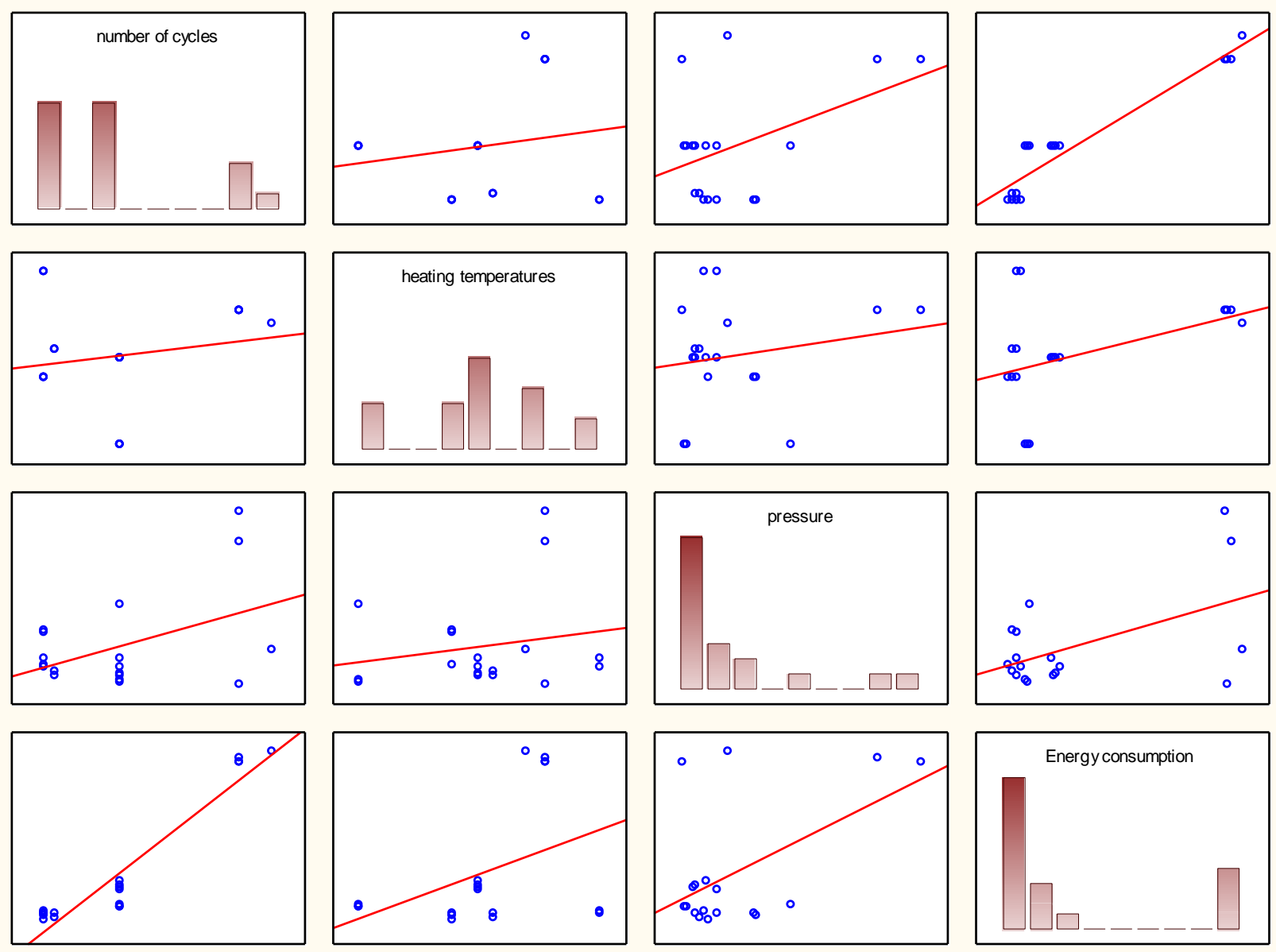

Figure 4. The prediction model for the energy consumption—matrix correlation plot.

The prediction model for the energy consumption was verified on the real data of the low-pressure carburising processes (Table 3). 
Table 3. Real data of the low-pressure carburising processes.

\begin{tabular}{ccccccc}
\hline No. & $\begin{array}{c}\text { Number of } \\
\text { Cycles- } \mathbf{X}_{\mathbf{1}}\end{array}$ & $\begin{array}{c}\text { Heating } \\
\text { Temperatures- } \mathbf{X}_{\mathbf{2}}\left({ }^{\circ} \mathbf{C}\right)\end{array}$ & $\begin{array}{c}\text { Pressure- } \mathbf{X}_{3} \\
(\mathbf{m b a r})\end{array}$ & $\begin{array}{c}\text { A Real Energy } \\
\text { Consumption } \\
(\mathbf{k W h})\end{array}$ & $\begin{array}{c}\text { A Prediction for the } \\
\text { Energy Consumption } \\
\mathbf{( k W h )}\end{array}$ \\
\hline 1 & 11 & 950 & 2.03 & 41.77 & 39.58 & $\begin{array}{l}-95.0 \% \mathrm{Gu}=36.62 ; \\
+95.0 \% \mathrm{Gu}=42.57 \\
-95.0 \% \mathrm{Gu}=36.57 ; \\
+95.0 \% \mathrm{Gu}=42.53\end{array}$ \\
\hline
\end{tabular}

Using the predictive model constructed, (Equation (1)), it is possible to determine the level of energy consumption $(\mathrm{kWh})$ during the carburisation process for a defined thickness of the carburisation layer.

\section{Discussion}

In the low-pressure carburizing process, three phases can be distinguished due to energy consumption:

- $\quad$ pumping the furnace down to target pressure;

- $\quad$ heating the furnace to the target temperature; and

- maintaining the appointed temperature and pressure during the carburizing process.

For our research purposes, 18 carburising experiments were performed with different carbon layers, at different input parameters, such as the number of cycles, time, temperature and average carburising pressure, in order to build the predictive model of energy consumption. Moreover, to verify this model, two additional research experiments were conducted.

Based on the analysis of the research results, the following results can be presented:

- The energy consumption of the pump system depends to a large extent on the number of carburising cycles.

- In subsequent carburising cycles, the furnace pressure level increases with the supply of acetylene, or other technical gases, which means that the furnace's mechanical pump must operate more efficiently and the demand for electricity increases. Each subsequent carburising cycle requires a reduction in pressure in the furnace chamber, which is a direct result of increased energy consumption by the pumping system.

- The energy consumption of both the pump system and the heating system depends heavily on the duration of the carburising process.

- As stated above, in the introduction, both sub-systems consume the most energy and each minute of the process is associated with a certain consumption of electrical energy.

- The energy consumption of the pumping system depends on the average pressure in the carburising process.

- A relatively efficient pumping system allows a pre-determined vacuum value to be achieved in a relatively short time. The power consumption of the pump system, required for a certain value of the vacuum, is constant.

- The energy consumption of the heating system does not depend to any great extent on the heating temperature.

- It can be assumed that the higher the heating temperature, the greater the energy demand of the heating system. According to the research, obtaining a higher temperature, through the heating system, only requires the consumption of more electricity temporarily. When the set temperature, viz., the maximum electricity consumption, is reached, the energy demand decreases, since only the temperature in the furnace chamber has to be maintained. Therefore, it is possible to obtain better carburisation characteristics by using higher temperatures, at lower pressures and in a shorter time. Such settings of the input parameters will result in a reduction in the energy consumption of the carburisation process. 
Energy consumption is one of the key sources of environmental impact. Predicting the energy consumption in the context of I.4.0. contributes to the long-term sustainable development (SD) of the manufacturing and the building of a circular economy. SD consists of three foundations: social, economic and environmental, the objective of which is to meet the resource needs of current and future generations without hampering the environment [21]. Liu et al. stated [22] that the energy consumption of aerospace parts in the use phase plays an important role in the total energy consumption, and therefore they formulated a decision-making model for comparing the energy demand of additivesubtractive hybrid manufacturing and conventional subtractive manufacturing based on the lifecycle method. Man et al. [23] developed an approach to understanding the energy consumption and energy-saving potential in a lifecycle perspective within a papermaking industry. Riedelsheimer et al. [24] emphasized the need to build digital twin models of the actual production energy consumption and the use phase energy consumption. Our prediction model for the energy consumption of a low-pressure carburising process can be further used to estimate the total energy consumption of this processes and to identify the most suitable sustainable parameters. Moreover, our approach should be integrated with the other I4.0 technologies introduced within an enterprise, e.g., mobile platforms that can accomplish tasks in workspaces [25], but this requires further work in this area.

\section{Conclusions}

This research was carried out based on the actual carburizing procedures used in industrial practice. Based on the research experiments conducted and statistical analysis, the influence of individual parameters on the energy consumption of the pump and heating systems was determined, and it was found that the energy consumption of the pump system depends to a large extent on the number of carburising cycles; the energy consumption of the heating system depends on the average pressure in the carburising process. Moreover, the energy consumption of the heating system does not depend to any great extent on the heating temperature.

This research can be used as an assistive tool for predicting the energy consumption of low-pressure carburising processes. To improve the prediction model's quality and the decision-making process in the context of the energy consumption of the pump system and heating system of the low-pressure carburising processes, further validation should be provided. Furthermore, as more data are obtained, it is expected that the accuracy of the model will increase.

Author Contributions: Conceptualization, J.P.-M. and S.K.; methodology, J.P.-M., S.K., Ł.P., K.W.; software, J.P.-M., S.K., Ł.P., K.W.; validation, J.P.-M., S.K., Ł.P., K.W.; formal analysis, S.K. and J.P.-M.; investigation, J.P.-M. and S.K.; resources, Ł.P. and K.W.; data curation, J.P.-M. and S.K.; writingoriginal draft preparation, J.P.-M. and S.K., Ł.P., K.W.; writing-review and editing, J.P.-M. and S.K.; visualization, J.P.-M. and S.K.; supervision J.P.-M. and S.K. project administration J.P.-M. and S.K.; funding acquisition, S.K. and J.P.-M. All authors have read and agreed to the published version of the manuscript.

Funding: POIR.04.01.02-00-0064/17 project and is co-financed by the European Union and the National Centre for Research and Development.

Institutional Review Board Statement: Not applicable.

Informed Consent Statement: Not applicable.

Data Availability Statement: Not applicable.

Acknowledgments: This article was elaborated as the result of the POIR.04.01.02-00-0064/17 project and is co-financed by the European Union and the National Centre for Research and Development.

Conflicts of Interest: The authors declare no conflict of interest. 


\section{References}

1. Nakagawa, T. Periodic and sequential preventive maintenance policies. J. Appl. Probab. 1986, 23, 536-542. [CrossRef]

2. Sun, Y.; Wang, S.; Xiao, F.; Gao, D. Peak load shifting control using different cold thermal energy storage facilities in commercial buildings. Energy Convers. Manag. 2013, 71, 101-114. [CrossRef]

3. Cauchi, N.; Macek, K.; Abate, A. Model-based predictive maintenance in building automation systems with user discomfort. Energy 2017, 138, 306-315. [CrossRef]

4. Macek, K.; Endel, P.; Cauchi, N.; Abate, A. Long-term predictive maintenance: A study of optimal cleaning of biomass boilers. Energy Build. 2017, 150, 111-117. [CrossRef]

5. Mobley, R.K. An Introduction to Predictive Maintenance, 2nd ed.; Plant Engineering, Butterworth-Heinemann: Oxford, UK, 2002; pp. 217-255.

6. Efthymiou, K.; Papakostas, N.; Mourtzis, D.; Chryssolouris, G. On a predictive maintenance platform for production systems. Procedia CIRP 2012, 3, 221-226. [CrossRef]

7. Sakib, N.; Wuest, T. Challenges and opportunities of condition-based predictive maintenance: A review. Procedia CIRP 2018, 78, 267-272. [CrossRef]

8. Wang, Z.; Srinivasan, R.S. A review of artificial intelligence based building energy use prediction: Contrasting the capabilities of single and ensemble prediction models. Renew. Sustain. Energy Rev. 2017, 75, 796-808. [CrossRef]

9. Cline, B.; Niculescu, R.S.; Huffman, D.; Deckel, B. Predictive maintenance applications for machine learning. In Proceedings of the Annual Reliability and Maintainability Symposium (RAMS), Orlando, FL, USA, 23-26 January 2017.

10. Paolanti, M.; Romeo, L.; Felicetti, A.; Mancini, A.; Frontoni, E.; Loncarski, J. Machine Learning approach for Predictive Maintenance in Industry 4.0. In Proceedings of the 14th IEEE/ASME International Conference on Mechatronic and Embedded Systems and Applications, MESA, Oulu, Finland, 2-4 July 2018.

11. Susto, G.A.; Schirru, A.; Pampuri, S.; McLoone, S.; Beghi, A. Machine learning for predictive maintenance: A multiple classifier approach. IEEE Trans. Ind. Inform. 2015, 11, 812-820. [CrossRef]

12. Schmidt, B.; Wang, L. Cloud-enhanced predictive maintenance. Int. J. Adv. Manuf. Technol. 2018, 99, 5-13. [CrossRef]

13. Jacquet, P.; Rousse, D.R.; Bernard, G.; Lambertin, M. A novel technique to monitor carburizing processes. Mater. Chem. Phys. 2003, 77, 542-551. [CrossRef]

14. Bruncko, M.; Rudolf, R.; Kosec, B.; Anzel, I. Vacuum carburizing of steels. Tech. Technol. Educ. Manag. 2012, 7, $1516-1521$.

15. Mulin, H.; Jacquet, P.; Lambertin, M.; Rossignol, B.; Faure, M. Monitoring carbon diffusion during a low pressure carburizing process. In Proceedings of the 17th IFHTSE Congress, Kobe, Japan, 27-30 October 2008.

16. Kula, P.; Pietrasik, R.; Paweta, S.; Dybowski, K.; Kaczmarek, L.; Gladka, A. High temperature low pressure carburizing with prenitriding process-The economic option for vacuum carburizing. Chiang Mai J. Sci. 2013, 40, 865-873.

17. Kamble, S.S.; Gunasekaran, A.; Gawankar, S.A. Sustainable Industry 4.0 framework: A systematic literature review identifying the current trends and future perspectives. Process Saf. Environ. Prot. 2018, 17, 408-425. [CrossRef]

18. Pangestu, P.; Pujiyanto, E.; Rosyidi, C.N. Multi-objective cutting parameter optimization model of multi-pass turning in CNC machines for sustainable manufacturing. Heliyon 2021, 7, 2. [CrossRef] [PubMed]

19. Kula, P.; Pietrasik, R.; Dybowski, K. Vacuum carburizing-Process optimization. J. Mater. Process. Technol. 2005, 164-165, 876-881. [CrossRef]

20. Li, Z.; Wang, K.; He, Y. Industry 4.0-Potentials for Predictive Maintenance. 6th International Workshop of Advanced Manufacturing and Automation (IWAMA 2016), 11, 2016. Available online: https://www.atlantis-press.com/proceedings/iwama-16/258 62217 (accessed on 21 June 2021).

21. Khan, I.S.; Ahmad, M.O.; Majava, J. Industry 4.0 and sustainable development: A systematic mapping of triple bottom line, Circular Economy and Sustainable Business Models perspectives. J. Clean. Prod. 2021, 297, 126655. [CrossRef]

22. Liu, W.; Deng, K.; Wei, H.; Zhao, P.; Li, K.; Zhang, Y. A decision-making model for comparing the energy demand of additivesubtractive hybrid manufacturing and conventional subtractive manufacturing based on life cycle method. J. Clean. Prod. [CrossRef]

23. Man, Y.; Han, Y.; Li, J.; Hong, M. Review of energy consumption research for papermaking industry based on life cycle analysis. Chin. J. Chem. Eng. 2019, 27, 1543-1553. [CrossRef]

24. Riedelsheimer, T.; Gogineni, S.; Stark, R. Methodology to develop Digital Twins for energy efficient customizable IoT-Products. Procedia CIRP 2021, 98, 258-263. [CrossRef]

25. Pajak, G.; Pajak, I. Planning of a point to point collision-free trajectory for mobile manipulators. In Proceedings of the 10th International Workshop on Robot Motion and Control (RoMoCo), Poznan, Poland, 6-8 July 2015; pp. $142-147$. 